\title{
A new species of Synopeas (Hymenoptera: Platygastridae) parasitizing Pauropsylla cf. depressa (Psylloidea: Triozidae) in India
}

\author{
Kamalanathan VEENAKUMARI ${ }^{1, *)}$, Peter Neerup BUHL ${ }^{2)} \&$ Prashanth MOHANRAJ') \\ 1) National Bureau of Agricultural Insect Resources, P.B. No. 2491, Hebbal, 560024 Bangalore, India; e-mail: veenapmraj@gmail.com; \\ veenaprashi@rediffmail.com \\ 2) Troldhøjvej 3, DK-3310 Ølsted, Denmark; e-mail: pnbuhl@hotmail.com \\ *) corresponding author
}

\author{
Accepted: \\ $23^{\text {rd }}$ April 2018 \\ Published online: \\ $29^{\text {th }}$ May 2018
}

\begin{abstract}
Synopeas pauropsyllae Veenakumari \& Buhl, sp. nov., a new species of Synopeas Förster, 1856 (Hymenoptera: Platygastroidea: Platygastridae: Platygastrinae), is recorded from galls induced by Pauropsylla cf. depressa Crawford, 1912 (Hemiptera: Psylloidea: Triozidae) on Ficus benghalensis L. (Moraceae) in India. It is concluded that S. pauropsyllae is a parasitoid of this psyllid species. This is the first record of a platygastrid parasitizing this host.
\end{abstract}

Key words. Hymenoptera, parasitoid wasp, Hemiptera, Sternorrhyncha, psyllid, taxonomy, gall, host plant, Ficus, India, Oriental Region

Zoobank: http://zoobank.org/urn:lsid:zoobank.org:pub:5D64E6E7-2F4C-4B40-821F-CBF20E864D7D

(C) 2018 The Authors. This work is licensed under the Creative Commons Attribution-NonCommercial-NoDerivs 3.0 Licence.

\section{Introduction}

With more than 5700 species and 264 genera, Platygastroidea is the third largest superfamily in the parasitic Hymenoptera after Ichneumonoidea and Chalcidoidea (Austin et al. 2005, JoHnson 2017). Platygastroidea includes two families, Scelionidae and Platygastridae. Scelionidae are idiobiont endoparasitoids of eggs of insects (viz. Orthoptera, Coleoptera, Lepidoptera, Mantodea, Odonata, Heteroptera and Embioptera) and spiders while Platygastridae are koinobiont parasitoids of immature stages of Auchenorrhyncha and Sternorrhyncha (Hemiptera) or Cecidomyiidae (Diptera) (Austin et al. 2005, MASNER 1993, TAEKUl et al. 2014). The checklist of Indian Platygastridae by Rajmohana \& Divya (2011) indicated the presence of 17 genera and 79 species in the country. The mega-diverse genus Synopeas Förster, 1856 which has a worldwide distribution is represented by 23 species in India (RAJMOHANA \& Divya 2011; VeEnaKumari et al. 2014, 2015).

Several insect orders such as Diptera, Hemiptera, Hymenoptera, Lepidoptera, Coleoptera and Thysanoptera are known to induce galls on plants (RAMAN \& ANANTHAKRISHNAN 1983, SkuHravá \& SkuhravÝ 2010, Yang \& Raman 2007, NARENDRAN et al. 2007, MANi 2000). Hemipterans inducing plant galls are mostly scale insects, aphids and psyllids. Among psyllids (Hemiptera: Sternorrhyncha: Psylloidea), several families are known to induce galls; gall-making species are particularly numerous in Triozidae, Phacopteronidae and Calophyidae (BurckHARDT 2005).

Platygastrinae are well-known parasitoids of gall-making species of Cecidomyiidae (Diptera) (MASNER 1993) and have rarely been reported as parasitoids of psyllids. In India, Inostemma apsyllae Austin, 1984 was described from the galls of Apsylla cistellata (Buckton, 1896) (Hemiptera: Psylloidea: Aphalaridae: Rhinocolinae) on mango (Mangifera indica L., Anacardiaceae) by Austin (1984). However, Austin (1984) considered this parasitoid-host insect association as doubtful and hypothesised that $I$. apsyllae might rather be a parasitoid of a cecidomyiid associated with $A$. cistellata. Here we report for the first time an association of a species of the platygastrid genus Synopeas Förster, 1856 with the galls of a Pauropsylla Förster, 1848 species (Hemiptera: Psylloidea: Triozidae) on the banyan fig tree, Ficus benghalensis L. (Moraceae). We describe this species of Synopeas as new and provide illustrations of its diagnostic characters and the psyllid galls from which it was reared. 


\section{Material and methods}

Leaf galls induced by Pauropsylla cf. depressa on Ficus benghalensis (Fig. 9) were cleaned thoroughly using cotton and water on both surfaces and incubated in plastic covers in the laboratory. Fourteen specimens (12 females and 2 males) of a new species of Synopeas were obtained from the galls. No other insect species was found in the incubation chambers. It is therefore surmised that Pauropsylla cf. depressa is the host of this platygastrid. This however requires confirmation as the rearing methods adopted here did not completely preclude the chances of the presence of other host insects. All specimens were reared by K. Veenakumari.

The specimens were mounted on point-card tips. The holotype and paratypes are deposited in the National Bureau of Agricultural Insect Resources, Bengaluru, India (NBAIR).

The description, measurements and imaging were carried out with a Leica M205A automontage stereomicroscope, with $1 \times$ objective and a Leica DFC-500 digital camera. The images were stacked using Leica Application Suite (LAS) software. Morphological terminology follows Masner \& Huggert (1989) and Mikó et al. (2007, 2010). All the measurements were taken as per Mıкó et al. (2010). Widths of all metasomal tergites were taken anteriorly.

The following abbreviations are used throughout the text:

A1-A10 - antennomeres $1-10(\mathrm{~A} 1$ = scape, $\mathrm{A} 2$ = pedicel $)$;

FCI (frontal cephalic index) $=\mathrm{HW} / \mathrm{HH}$;

$\mathrm{H}$ - height;

$\mathrm{HH}$ - head height;

HL - head length;

HW - head width

IOS - interorbital space;

L - length;

LCI (lateral cephalic index) $=\mathrm{HH} / \mathrm{HL}$;

LOL - lateral ocellar line;

OOL - ocular ocellar line;

POL - posterior ocellar line;

T1-T6 - metasomal tergites 1 to 6 ;

S1-S2 - metasomal sternites 1 to 2 ;

$\mathrm{W}-$ width.

\section{Taxonomy}

Synopeas pauropsyllae Veenakumari \& Buhl sp. nov. (Figs 1-8)

Material examined. HоLотуре: $q$, INDIA: KARNATAKA: Bengaluru, Hebbal, $13^{\circ} 02^{\prime} 08^{\prime \prime} \mathrm{N} 77^{\circ} 35^{\prime} 49^{\prime \prime} \mathrm{E}, 906 \mathrm{~m}, 02$.XII.2011 (NBAIR, registration no. ICAR/NBAIR/P1920). PARATYPES: $11+q$ (nos. ICAR/NBAIR/ P1921-P1931) and $2 \hat{\jmath}$ (nos. ICAR/NBAIR/P1932-P1933), same data as holotype (NBAIR).

Description. Adult female. Body length: $1.24-1.37 \mathrm{~mm}$ $($ mean $=1.3, \mathrm{SD}=0.04, \mathrm{n}=11$; holotype $=1.3 \mathrm{~mm})$.

Colour. General body colour black. A1 and legs golden yellow except dark brown coxae, apices of femur and tibia and basitarsi of hind leg; clava dark brown, other antennomeres golden yellow (Figs 1, 5).

Head $($ Figs 1, 2, 4, 5). FCI $=1.23 ; \mathrm{LCI}=1.44$. IOS $0.65 \times$ width of head, shortest at the level of mid-frons; frons finely reticulate, sparsely setose; inverted V shaped striae present above toruli; hyperoccipital carina distinct, joining the posterior orbits; hyperoccipital carina extending anteromedially; occiput finely reticulate; compound eye bare, $\mathrm{L} / \mathrm{W}=19.4 / 13.1$; posterior ocellus contiguous with orbits; $\mathrm{POL}>\mathrm{LOL}$ in ratio of $24.4 / 10.5$; clypeus rectangular $(\mathrm{L} / \mathrm{W}=2.3 / 12.7)$; interantennal process projecting; length to width of antennomeres in ratios of 25.1/5.1, 6.7/3.1, 2.8/1.9, 5.5/2.0, 2.5/2.3, 3.7/3.0, 4.2/4.7, 5.1/5.7, 5.1/6.6, 7.7/5.7, respectively; radicle $0.1 \times$ length of A1.

Mesosoma (Figs 1-3, 6, 8). Mesoscutum as long as wide $(\mathrm{L} / \mathrm{W}=29.5 / 30.6)$, convex, sparsely setose, finely reticulate, reticulations longitudinally elongate medially; posteromedial margin of mesoscutum extending as a short triangular midlobe over mesoscutellum; axilla large, triangular, covered with 12 long white setae; scutoscutellar sulcus non-foveate; pronotum clearly visible from above, reticulate, sparsely setose; epomial carina faint; cervical pronotal area finely reticulate with anterior rim of pronotum smooth; upper lateral pronotal area reticulate and sparsely setose; lower lateral pronotal area smooth; entire mesopleuron smooth; metapleuron smooth with dense long white setae; mesoscutellum triangular, convex, smooth with a short upturned spine with a lamella posteromedially, $\mathrm{L} / \mathrm{W}=13.7 / 20.4$; lateral keel broad anteriorly and narrow posteriorly; metascutellum rectangular, smooth; metanotal trough smooth with two transverse median carinae (Fig. 8); propodeum with two median carinae placed close to each other; lateral propodeal area smooth with dense long white setae. Forewing (L/W = 88.7/39.4) and hind wing $(\mathrm{L} / \mathrm{W}=$ 77.5/14.1) hyaline, with sparse microtrichia; forewing with no marginal cilia; hind wing cilia $0.25 \times$ width of wing.

Metasoma (Figs 1, 6). $\mathrm{L} / \mathrm{W}=41.6 / 34.4 ; \mathrm{T} 1$ short with median and submedian carinae; T2, entirely smooth with a row of long white setae on anterior margin; remaining tergites anteriorly smooth and with faint reticulations and sparse setae posteriorly; length and width of tergites T1-T6 in ratios of 3.9/11.6, 30.3/18.2, 2.3/32.7, 2.0/28.1, $1.4 / 24.1,3.5 / 18.7$, respectively; anterior margin of $\mathrm{S} 2$ with dense setae.

Adult male. Similar to female. Body length 1.24-1.28 $\mathrm{mm}($ mean $=1.26, \mathrm{SD}=0.03, \mathrm{n}=2)$.

Length and width of antennomeres A1-A10 in ratios of 25.6/5.2, 6.2/3.2, 2.2/2.1, 5.8/2.6, 4.3/2.5, 5.0/3.1, 6.0/3.6, $6.1 / 3.7,6.0 / 3.7,10.0 / 3.5$, respectively (Fig. 7). A3-A10 densely setose, length of setae $0.1 \times$ length of A1. Metasoma $\mathrm{L} / \mathrm{W}=37.3 / 30.1$, with seven tergites; length and width of tergites T1-T7 in ratios of 3.6/14.1, 24.0/17.6, 2.9/29.3, $2.9 / 26.5,2.1 / 21.2,1.7 / 14.8,1.3 / 8.3$, respectively.

Variability. Not much variation was found between specimens except for differences in size as mentioned above. This could possibly be the result of all specimens being obtained from a single batch of galls.

Differential diagnosis. This new species of Synopeas is similar to S. involutum Kieffer, 1926, S. pinnei Buhl, 2009, S. mangiferae Austin, 1984 and S. fuscum Buhl, 1998 but differs from them in the following combination of character states: presence of hyperoccipital carina, OOL not distinct, dense setae along hind margin of mesoscutum, shape of scutellum and unusually short female T3-T6. While $S$. involutum, S. pinnei and S. fuscum are distributed in the Palaearctic Region, S. mangiferae is an Oriental species 


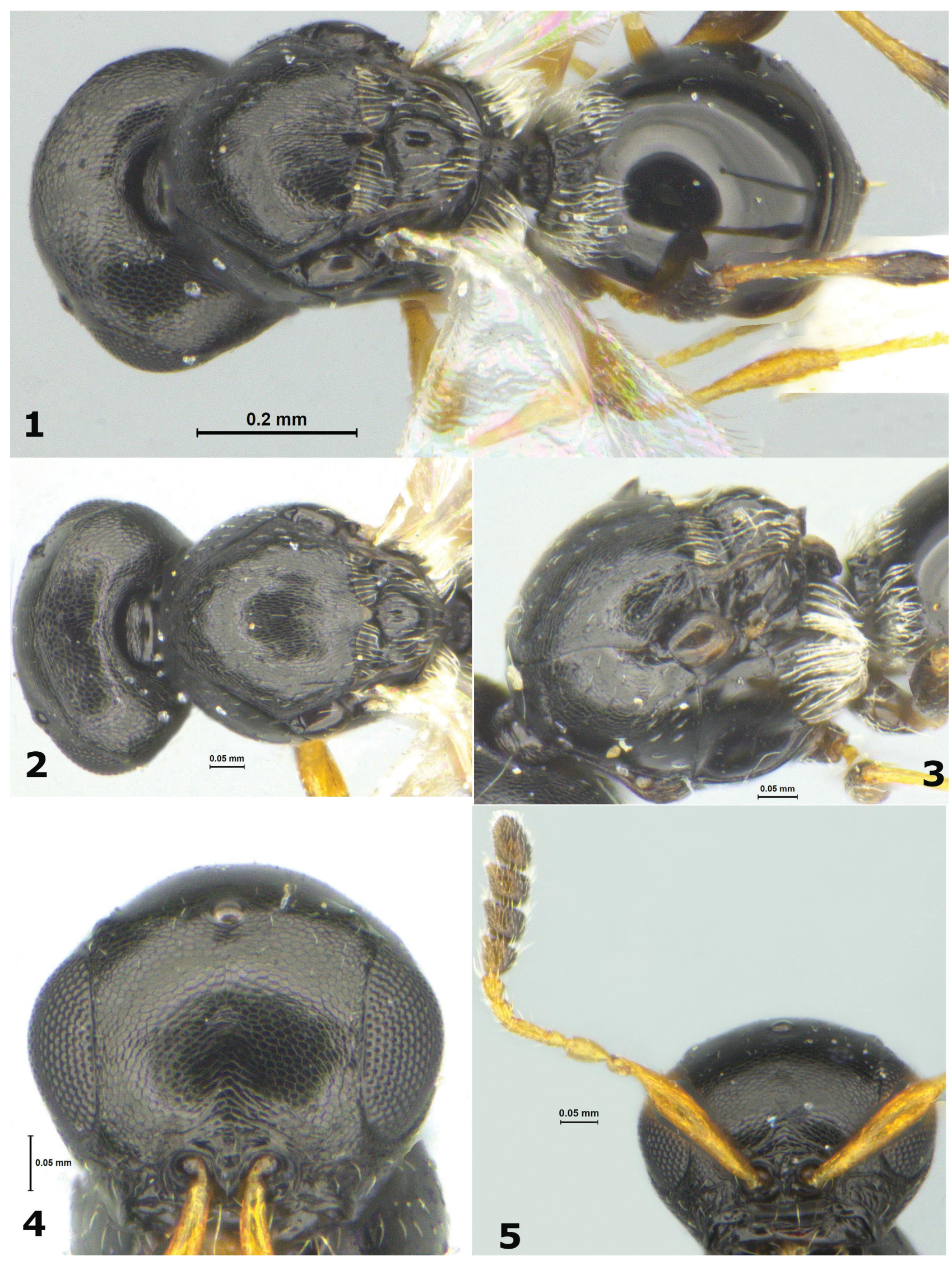

Figs 1-5. Synopeas pauropsyllae sp. nov. 1 - habitus, dorsal view; 2 - head and mesoscutum; 3 - mesoscutum, lateral view; 4 -frons; 5 -frons and female antenna. 
known from India (KIEFFer 1926; Austin 1984; BuHL 1998, 2009).

Biology. All specimens emerged from galls induced by Pauropsylla $\mathrm{cf}$. depressa (Hemiptera: Psylloidea: Triozidae) on isolated trees of Ficus benghalensis (Figs 9-12) situated in rainfed agricultural land. The adult male psyllid that emerged from the galls closely resembles $P$. depress $a$ Crawford, 1912 as redescribed by MATHUR (1975) in the structure of the head and antenna, the shape and venation of the fore wing and probably also in the paramere shape, but a more detailed study of the material is needed to confirm the identity (I. Malenovský \& D. Burckhardt, pers. comm.). Pauropsylla depressa is a widely distributed species in India including Karnataka; it has so far been known to induce galls on Ficus racemosa L. (Mathur 1975, D’Souza \& RAVISHANKAR 2014). Etymology. This species is named 'pauropsyllae' based on the generic name of the host of this parasitoid; noun in genitive case standing in apposition.
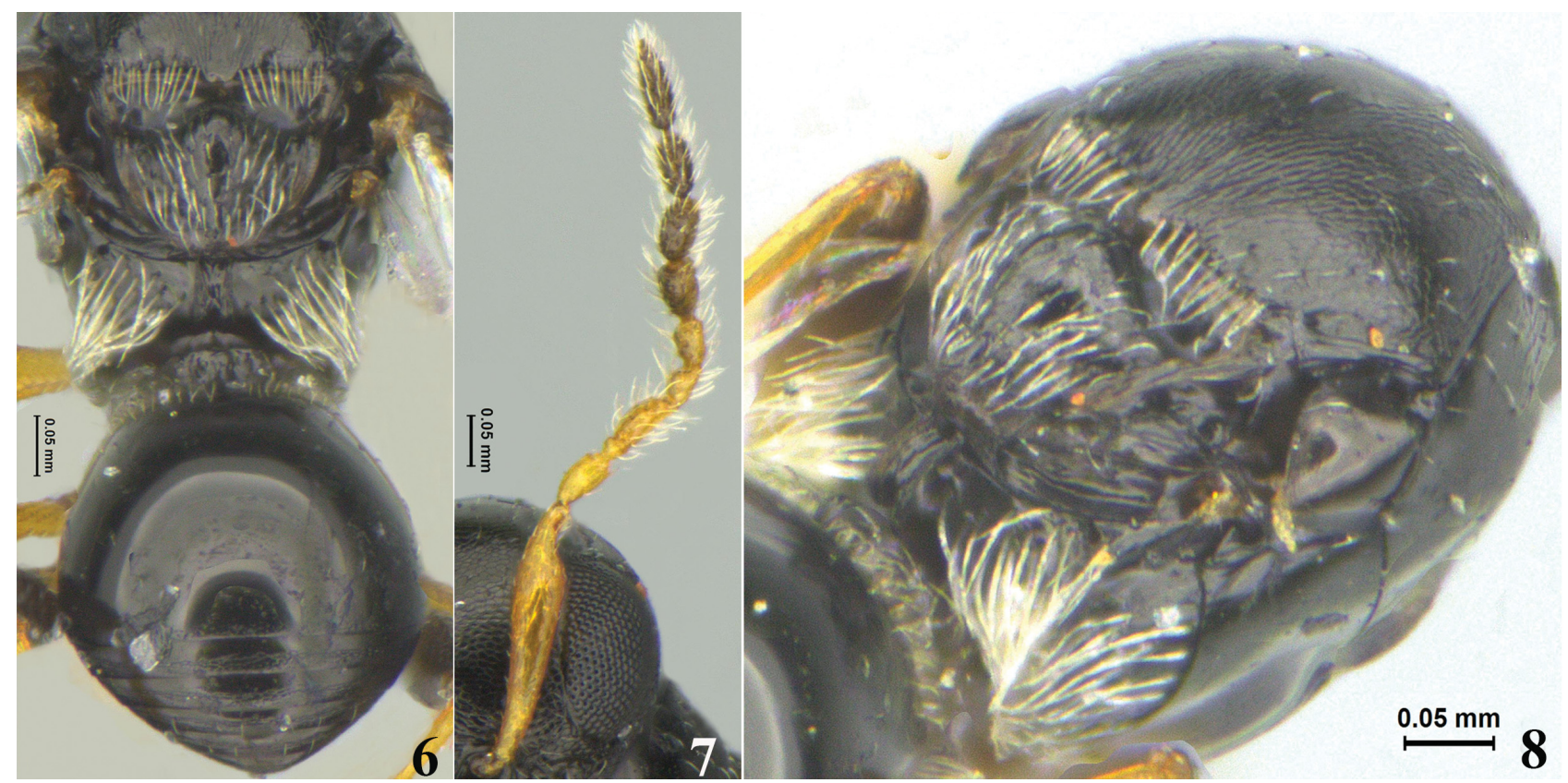

Figs 6-8. Synopeas pauropsyllae sp. nov. 6 - propodeum and metasoma; 7 - male antenna; 8 - metanotum and propodeum, lateral view.

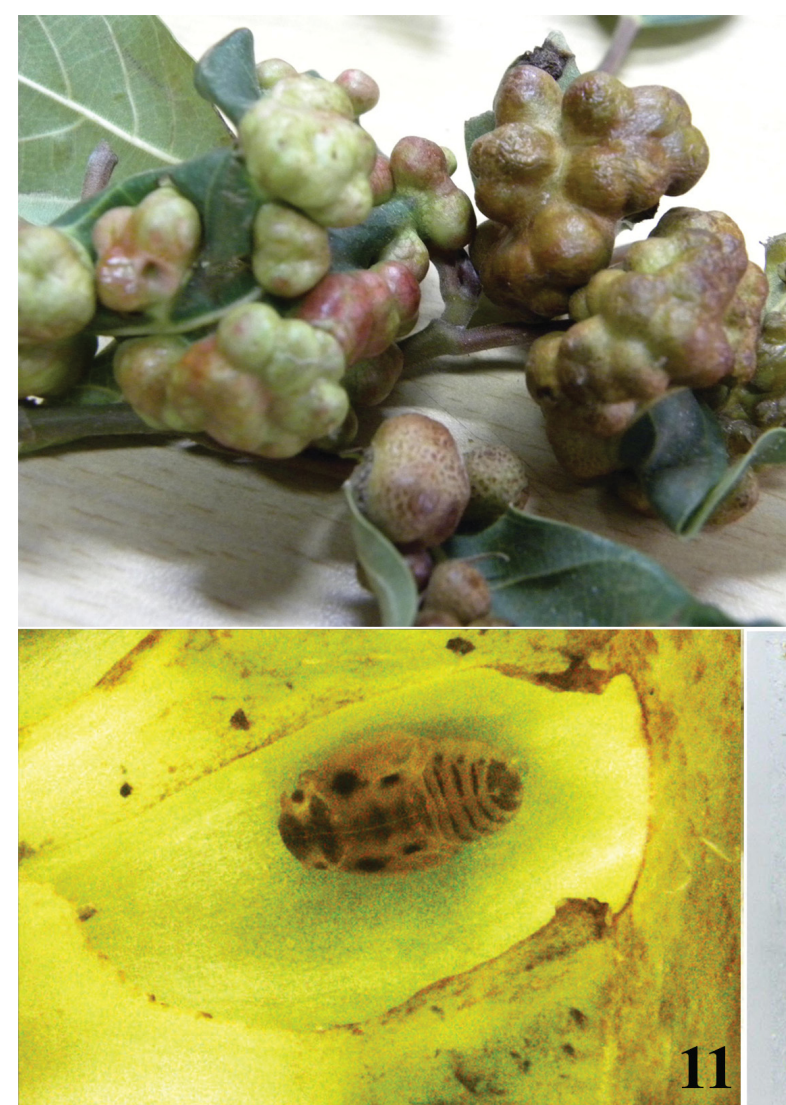

9

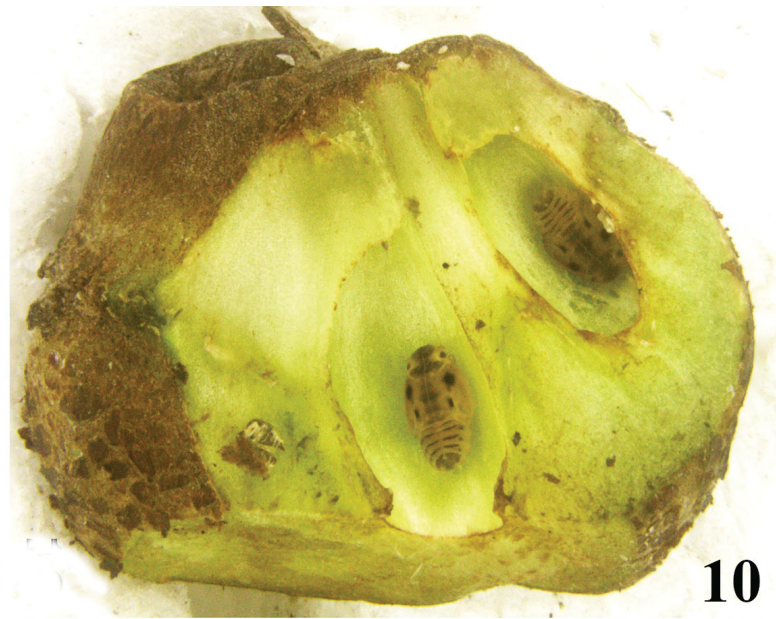

Figs 9-12. Host of Synopeas pauropsyllae sp. nov. 9 - galls on Ficus benghalensis leaves; 10 - cross section of a gall showing two nymphs of Pauropsylla cf. depressa Crawford, 1912 in the cavities; 11 - close up of a nymph of $P$. cf. depressa; 12 - lateral view of an adult male of $P$. cf. depressa. 


\section{Acknowledgements}

The first and last authors are grateful to the Director (NBAIR, Bangalore, India) for providing facilities and encouragement. We thank I. Malenovský (Masaryk University, Brno, Czech Republic) and D. Burckhardt (Naturhistorisches Museum, Basel, Switzerland) for the identification of the psyllid. We thank V. Shashikala and B. Nagaraja for their support both in the field and laboratory. Thanks are also due to the Platygastroidea Planetary Biodiversity Inventory, under National Science Foundation grant No. DEB-0614764, for literature support.

\section{References}

AUSTIN A. D. 1984: New species of Platygastridae (Hymenoptera) from India which parasitise pests of mango, particularly Procontarinia spp. (Diptera: Cecidomyiidae). Bulletin of Entomological Research 74: 549-557.

AUSTIN A. D., JOHNSON N. F. \& DOWTON M. 2005: Systematics, evolution, and biology of scelionid and platygastrid wasps. Annual Review of Entomology 50: 553-582.

BUHL P. N. 1998: Platygastridae (Hymenoptera) species of a Juniperus thurifera L. forest of Los Monegros region (Zaragoza, Spain). Zapateri, Revista Aragonensa de Entomologia 8: 11-42.

BUHL P. N. 2009: New or little known Palaearctic species of Platygastrinae (Hymenoptera: Platygastridae). III. Entomologica Fennica 20: $65-83$.

BURCKHARDT D. 2005: Biology, ecology, and evolution of gall-inducing psyllids (Hemiptera: Psylloidea). Pp. 143-157. In: RAMAN A., SCHAEFER C. W. \& WITHERS T. M. (eds): Biology, ecology, and evolution of gall inducing arthropods. Science Publishers, New Enfield-Plymouth, USA, 817 pp.

D'SOUZA M. R. \& RAVISHANKAR B. E. 2014: Nutritional sink formation in galls of Ficus glomerata Roxb. (Moraceae) by the insect Pauropsylla depressa (Psyllidae, Hemiptera). Tropical Ecology 55: 129-136.

JOHNSON N. F. 2017: Platygastroidea. Available online: http://osuc. biosci.ohio-state.edu/hymDB/eol_scelionidae.home (accessed on 6.xi.2017).

KIEFFER J. J. 1926: Scelionidae. Das Tierreich. Vol. 48. Walter de Gruyter \& Co., Berlin, 885 pp.

MANI M. S. 2000: Plant galls of India. Second edition. Science Publishers, Enfield, New Hampshire, USA, 477 pp.
MASNER L. 1993: Superfamily Platygastroidea. Pp. 558-563. In: GOULET H. \& HUBER J. T. (eds): Hymenoptera of the world: An identification guide to families. Canada Communication Group-Publishing, Ottawa, Canada, 668 pp.

MASNER L. \& HUGGERT L. 1989: World review and keys to genera of the subfamily Inostemmatinae with reassignment of the taxa to the Platygastrinae and Sceliotrachelinae (Hymenoptera: Platygastridae). Memoirs of the Entomological Society of Canada 147: 1-214.

MATHUR R. N. 1975: Psyllidae of the Indian subcontinent. Indian Council of Agricultural Research, New Delhi, 429 pp.

MIKÓ I., MASNER L. \& DEANS A. R. 2010: World revision of Xenomerus Walker (Hymenoptera: Platygastroidea, Platygastridae). Zootaxa 2708: 1-73.

MIKÓ I., VILHELMSEN L., JOHNSON N. F., MASNER L. \& PÉNZES Z. 2007: Skeleto-musculature of Scelionidae (Hymenoptera: Platygastroidea) head and mesosoma. Zootaxa 1571: 1-78.

NARENDRAN T. C., SANTHOSH S. \& SUDHEER K. 2007: Biosystematics and biogeography of Oriental Chalcidoidea (Hymenoptera) associated with plant galls. Oriental Insects 41: 141-167.

RAJMOHANA K. \& DIVYA K. P. 2011: Checklist of Platygastrinae and Sceliotrachelinae (Hymenoptera: Platygastridae) of India. Available online: http://zsi.gov.in/WriteReadData/userfiles/file/Checklist/Checklist $\% 20$ Platygastrinae\%20and\%20Sceliotrachelinae.pdf (accessed on 6.xi.2017).

RAMAN A. \& ANANTHAKRISHNAN T. N. 1983: Studies on some thrips (Thysanoptera, Insecta) induced galls. 1. Developmental morphology. Proceedings of Indian National Science Academy 49: 313-358.

SKUHRAVÁ M. \& SKUHRAVÝ V. 2010: Species richness of gall midges (Diptera: Cecidomyiidae) in Europe (West Palaearctic): Biogeography and coevolution with host plants. Acta Societatis Zoologicae Bohemicae 73: 87-156.

TAEKUL C., VALERIO A. A., AUSTIN A. D., KLOMPEN H. \& JOHNSON N. F. 2014: Molecular phylogeny of telenomine egg parasitoids (Hymenoptera: Platygastridae s.1.: Telenominae): evolution of host shifts and implications for classification. Systematic Entomology 39: $24-35$.

VEENAKUMARI K., BUHL P. N. \& MOHANRAJ P. 2015: Six new species of Platygastridae (Hymenoptera: Platygastroidea) from India. Entomologist's Monthly Magazine 151: 35-50.

VEENAKUMARI K., BUHL P. N., MOHANRAJ P. \& KHAN F. R. 2014: Four new species of Platygastridae (Hymenoptera: Platygastroidea) from India. Entomologist's Monthly Magazine 150: 49-60.

YANG M. \& RAMAN A. 2007: Diversity, richness, and patterns of radiation among gall-inducing psyllids (Hemiptera: Psylloidea) in the Orient and eastern Palaearctic. Oriental Insects 41: 55-65. 
